\title{
Ecology of amorphous aggregations (marine snow) in the Northern Adriatic Sea. IV. Dissolved nutrients and the autotrophic community associated with marine snow
}

\author{
Elisabeth Kaltenböck, Gerhard J. Herndl* \\ Department of Marine Biology, Institute of Zoology, University of Vienna, Althanstr. 14, A-1090 Vienna, Austria
}

\begin{abstract}
In the Northern Adriatic Sea, development over time of the inorganic nutrient regime as well as the autotrophic community was investigated in marine snow (up to $20 \mathrm{~cm}$ in diameter) and in clouds (up to $5 \mathrm{~m}$ in length) in summer 1991. Inorganic nitrogen species did not follow a particular trend over the investigation period. In marine snow mean enrichment factors (EFs) for inorganic nitrogen species ranged from $2\left(\mathrm{NH}_{3}\right)$ to $3.5\left(\mathrm{NO}_{2}{ }^{-}\right)$while for $\mathrm{PO}_{4}{ }^{3-}$ a mean $\mathrm{EF}$ of 27 was obtained. Clouds exhibited generally similar EFs. In ambient water, the mean atomic ratio of $\mathrm{N}_{1 \text { norg }}: \mathrm{P}_{-} \mathrm{PO}_{4}{ }^{3-} \mathrm{w}$ as ca 70 and therefore deviated significantly from the Redfield ratio of 16 . This severe deficiency in phosphate availability might be one of the triggering factors for excessive production of mucoid material by phytoplankton. The mean ratio of $\mathrm{N}_{\text {nnorg }}: \mathrm{P}_{-} \mathrm{PO}_{4}{ }^{3-}$ was 13 in marine snow, and 9 in clouds, indicating a tendency towards increasing nitrogen limitation for primary production as marine snow ages. During the investigation period, cyanobacteria contributed ca $75 \%$ to the total chl a concentration in ambient water and $68 \%$ in marine snow. Particulate primary production in marine snow (integrated over several irradiance levels) was about 10 times higher $\left(12.45 \mu \mathrm{g} \mathrm{Cl}^{-1} \mathrm{~h}^{-1}\right)$ than in ambient water and similar to the production in clouds while specific primary production in marine snow was significantly lower than in ambient water. In clouds specific productivity was ca 1 order of magnitude lower than in ambient water. Based on our measurements, we calculated that the inorganic nitrogen pool is turned over 5 times faster in marine snow than in ambient water while inorganic phosphorus is turned over twice as fast in ambient water. The estimated contribution of primary production associated with marine snow and clouds to overall water column primary production amounts to ca $40 \%$.
\end{abstract}

\section{INTRODUCTION}

The species composition of the phytoplanktonic component in aquatic ecosystems often follows a distinct succession regulated by physical factors such as light, turbulence and temperature and by biological factors like nutrient availability and grazing pressure (Sommer 1989). Only the oligotrophic equatorial waters (e.g. the Pacific gyres) maintain a relative stable and speciesrich phytoplankton community throughout the year. In these waters, cyanobacteria represent a prominent group of primary producers contributing up to $70 \%$ to the autotrophic production of organic matter (Li \& Platt 1987, Stockner 1988).

There is increasing evidence, however, that cyano-

- Addressee for correspondence bacteria may contribute significantly to temperate, coastal production as well. Especially during stratified summer conditions, cyanobacterial production may prevail over eukaryotic primary production (Joint \& Pomeroy 1983, Howard \& Joint 1989, Jochem 1989). The notion that cyanobacteria contribute significantly to autotrophic production during stratified summer conditions is of particular interest when we consider that marine snow phenomena occur during summer situations when the spring bloom is decaying and thereby releasing considerable amounts of high molecular weight polymers (Lancelot 1983). The released material coagulates and becomes mucoid particulate material; the size of these amorphous aggregates is a function of the shear forces these aggregates encounter (Alldredge et al. 1990, Alldredge \& McGillivary 1991). 
In the Northern Adriatic Sea, large amorphous aggregates have been reported to occur during prolonged periods of calm weather conditions which reduce the turbulence and hence the shear forces these particles encounter (Herndl \& Peduzzi 1988). The pycnocline plays an important role in the formation of these large amorphous aggregates by retaining the aggregates in the surface waters (Puskaric et al. 1992, Herndl et al. in press). Since the Northern Adriatic Sea experiences such long periods of reduced turbulence and strong stratification only during summer, it is reasonable to assume that free-living cyanobacteria might become trapped by the mucoid aggregates. Under such conditions cyanobacteria could potentially be important producers of organic matter within marine snow.

The occurrence of large masses of gelatinous aggregates in the Mediterranean was reported in summer 1991 not only in the Northern Adriatic Sea but also along the Spanish coast as well as in the Tyrrhenian Sea (Giuffré pers. comm.); the mucoid aggregates reported from these areas, however, never reached the size observed in the Northern Adriatic Sea (up to $5 \mathrm{~m}$ in length; authors' unpubl. data). We suggest that the question addressed in this paper of whether cyanobacteria play a major role as primary producers in marine snow and in large mucoid aggregations is not only relevant for a restricted area of the Mediterranean Sea such as the Northern Adriatic Sea; rather, it might also be of importance for the coastal waters in general where low turbulence, stratification and cyanobacterial blooms coincide.

We hypothesize that free-living cyanobacteria become entrapped in marine snow resulting in an increase in cyanobacterial biomass on the aggregates if they are able to cope with the specific nutrient conditions there and successfully compete with other phytoplankton species. Additionally, we aimed to follow the changes of the autotrophic component and the nutrient regime in marine snow over time by taking advantage of the characteristic current structure of the Northern Adriatic Sea. During summer, the Northern Adriatic Sea becomes more or less isolated from the oligotrophic Middle and Southern Adriatic Sea due to the counterclockwise current structure (Orlic et al. 1986, Orlic 1987). Thus, we were able to follow the fluctuations in nutrient concentrations, alkaline phosphatase activity and the autotrophic biomass of the aggregates, which were all probably of the same origin and developed at the same time, without the necessity of following one individual aggregate over a period of 3 mo. A paper on the fluctuations in organic nutrients and the heterotrophic microbial biomass in marine snow and large aggregates will be published elsewhere (Müller-Niklas \& Herndl unpubl. data).

\section{MATERIAL AND METHODS}

Study location and sampling procedure. The study was conducted in the northernmost part of the Northern Adriatic Sea in the Gulf of Trieste (Fig. 1) from the end of May to early September 1991. In situ sampling was performed by SCUBA divers in the water column (13 $\mathrm{m}$ depth) about $1.5 \mathrm{~km}$ off the Laboratorio di Biologia Marina at Trieste-Aurisina (Italy). Samples were taken with $60 \mathrm{ml}$ disposable syringes (rinsed with $0.1 \mathrm{~N} \mathrm{HCl}$ and distilled water prior to sampling). Due to the size of the aggregates (at least $2 \mathrm{~cm}$ in diameter) it was possible to sample these mucoid particles without inclusion of surrounding water; up to 10 aggregates were collected until the syringe was completely filled with marine snow while only a fraction of large clouds was sampled with each syringe. We define clouds as large gel-like aggregates with a length of up to $5 \mathrm{~m}$ (Fig. 2B). Surrounding water was also collected selectively by SCUBA divers at the same depth as the mucoid aggregates were sampled. Care was taken not to include visible particles in the 'ambient water' sample. Samples taken in this way were brought aboard the boat and returned to the Laboratorio di Biologia Marine at Aurisina-Trieste (Italy) in a cooling box kept in dark at ambient water temperature within $30 \mathrm{~min}$ for further processing.

Marine snow (Fig. 2A) or fractions of large aggregates (Fig. 2B) confined in syringes were carefully transferred into 125 or $500 \mathrm{ml}$ Erlenmeyer flasks (pre-treated with $10 \% \mathrm{HCl}$ and rinsed with distilled water). From these flasks subsamples were taken for all the biomass and production measurements and the inorganic nutrient concentrations described below, and additionally for microheterotrophic biomass determinations and bacterial secondary production estimates (Müller-Niklas \& Herndl unpubl.). Ambient water was poured into $1000 \mathrm{ml}$ Erlenmeyer flasks pre-treated in the same way as described above.

Autotrophic cell density, biomass and primary production measurements. In order to obtain an estimate of the autotrophic biomass present in ambient water and in the mucoid aggregates 11 of ambient water or $20 \mathrm{ml}$ of aggregates were filtered onto glass fiber filters (Whatman GF/F, $47 \mathrm{~mm}$ diameter) and kept frozen $\left(-20^{\circ} \mathrm{C}\right)$ until analysis. Clouds could not be filtered in a reasonable time; therefore $2 \mathrm{ml}$ of each of those aggregates were transferred into a glass vial and frozen. For chlorophyll a (chl a) determination, filters and the clouds, respectively, were extracted in $10 \mathrm{ml} 90 \%$ $(\mathrm{v} / \mathrm{v})$ acetone and stored refrigerated overnight. Before spectrophotometrically measuring chl a, both acetone extractions, those collected onto the filters and those of cloud material, were filtered through GF/F filters to remove particles. For calculating chl a concentrations 
Fig. 1. Study location in the Gulf of Trieste, Northern Adriatic Sea. The sampling location is marked by a circle

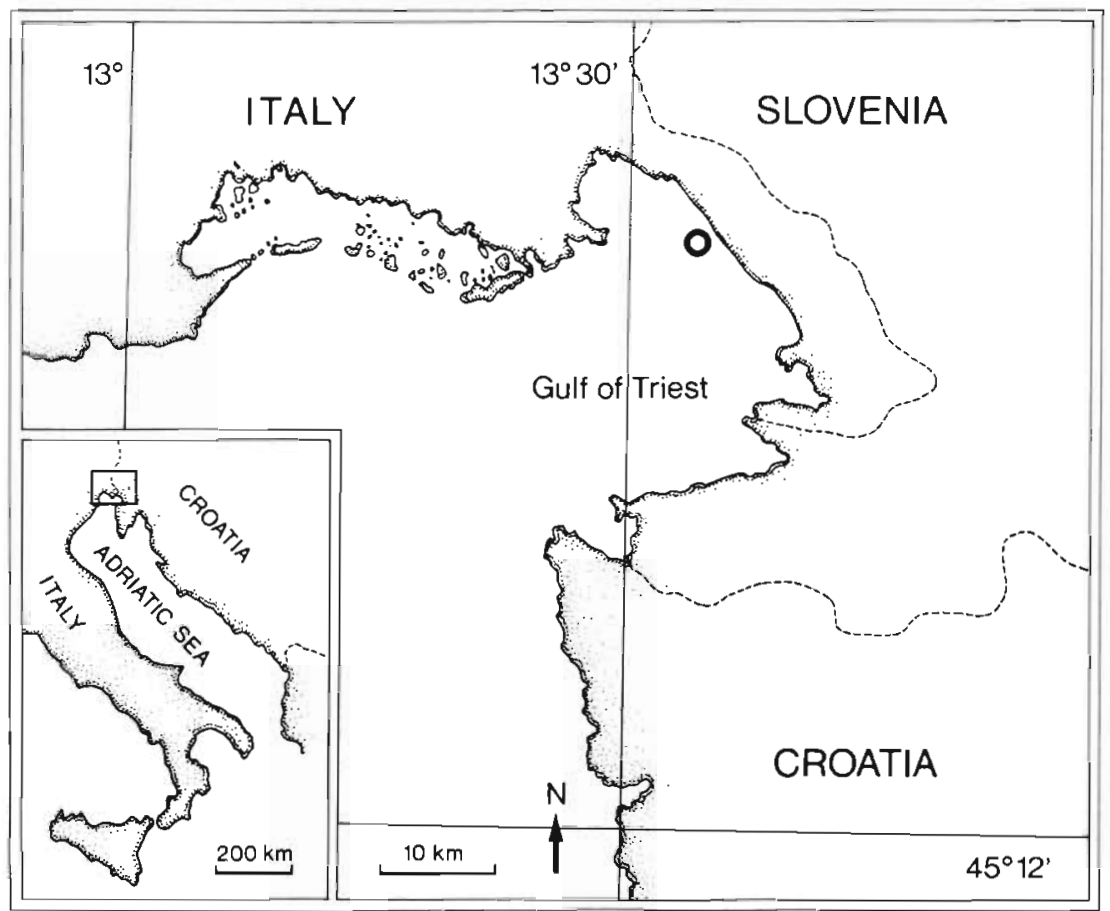

the method and formulas given in Parsons et al. (1984) were used.

To enumerate cyanobacteria, 20 to $40 \mathrm{ml}$ of ambient water and 1 to $4 \mathrm{ml}$ of marine snow respectively was filtered onto $0.45 \mu \mathrm{m}$ pore size black polycarbonate filters (filter diameter: $25 \mathrm{~mm}$, Poretics and Millipore). This pore size has been found to retain all cyanobacteria but allows faster filtration than using $0.2 \mu \mathrm{m}$ pore size. Subsequently, the filters were embedded in glycerol and stored frozen until microscopical examination (usually within $2 \mathrm{~d}$ ). Cyanobacteria were enumerated under a Leitz Laborlux S microscope equipped with a Ploemopak epifluorescence unit at a magnification of $1250 \times$. Only those particles were counted as cyanobacteria which exhibited yellow-orange autofluorescence with distinct regular cell boundaries.

To convert cyanobacterial density to carbon equivalents and chl a concentrations, cyanobacteria were isolated from selected ambient water and marine snow samples and cultivated in a modified $\mathrm{f} / 2$ medium following the protocol of Waterbury et al. (1986). In late exponential phase (determined by cell enumeration) cells were harvested by centrifuging $500 \mathrm{ml}$ of the culture at $1200 \times g$ for $20 \mathrm{~min}$. The pellet was resuspended 3 times in $20 \mathrm{ml}$ of artificial seawater, centrifuged and resuspended in $5 \mathrm{ml}$ of double-distilled water. The organic carbon content of the suspension was measured in a Beckman Tocamaster 915-B after homogenizing and acidifying the sample with $50 \mu \mathrm{l}$ of $10 \%(\mathrm{v} / \mathrm{v}) \mathrm{HCl}$ to a $\mathrm{pH}$ of 2 and purging with $\mathrm{C}$-free air for $10 \mathrm{~min}$. The instrument was calibrated with glucose as a standard. At least 3 replicate determinations were made per measurement. Prior to the centrifugation procedure, the abundance of cyanobacteria and heterotrophic bacteria (using DAPI staining as described in Porter \& Feig 1980) in the medium was determined. Bacterial density was converted into carbon equivalents using the conversion factor of $20 \mathrm{fg} \mathrm{C} \mathrm{Cell}^{-1}$ (Lee \& Fuhrman 1987) and subtracted from the total organic carbon (TOC) content of the concentrated suspension. The difference between the TOC content of the suspension and the bacterial carbon was assumed to be cyanobacterial carbon. Microscopical examination revealed that no other organisms were present in the medium besides cyanobacteria and heterotrophic bacteria. Only a few flagellates were present (well below $10^{3}$ flagellates $\mathrm{l}^{-1}$ medium). Their contribution to the TOC content of the medium was negligible. For estimating the chl a content per cyanobacterium, $20 \mathrm{ml}$ of the medium was filtered onto a Whatman GF/F and the chl a content spectrophotometrically determined as described above.

Primary production was estimated using the ${ }^{14} \mathrm{C}$ radiolabeling technique (Parsons et al. 1984). Winkler flasks $(100 \mathrm{ml})$ were filled with $100 \mathrm{ml}$ of ambient water while 10 to $20 \mathrm{ml}$ of marine snow and clouds were placed in $20 \mathrm{ml}$ scintillated vials (borosilicate glass). To each flask $1 \mathrm{ml}$ of $2 \mu \mathrm{Ci} \mathrm{m}{ }^{-1}$ sodium ${ }^{14} \mathrm{C}$-bicarbonate (S.A. $55.2 \mathrm{mCi} \mathrm{mmol}{ }^{-1}$, Amersham) was added and incubated in duplicates in an incubator on the shore at different irradiance levels $(90,50,30,10$ and $0 \%$ of surface irradiance) on sunny, cloudless days around 

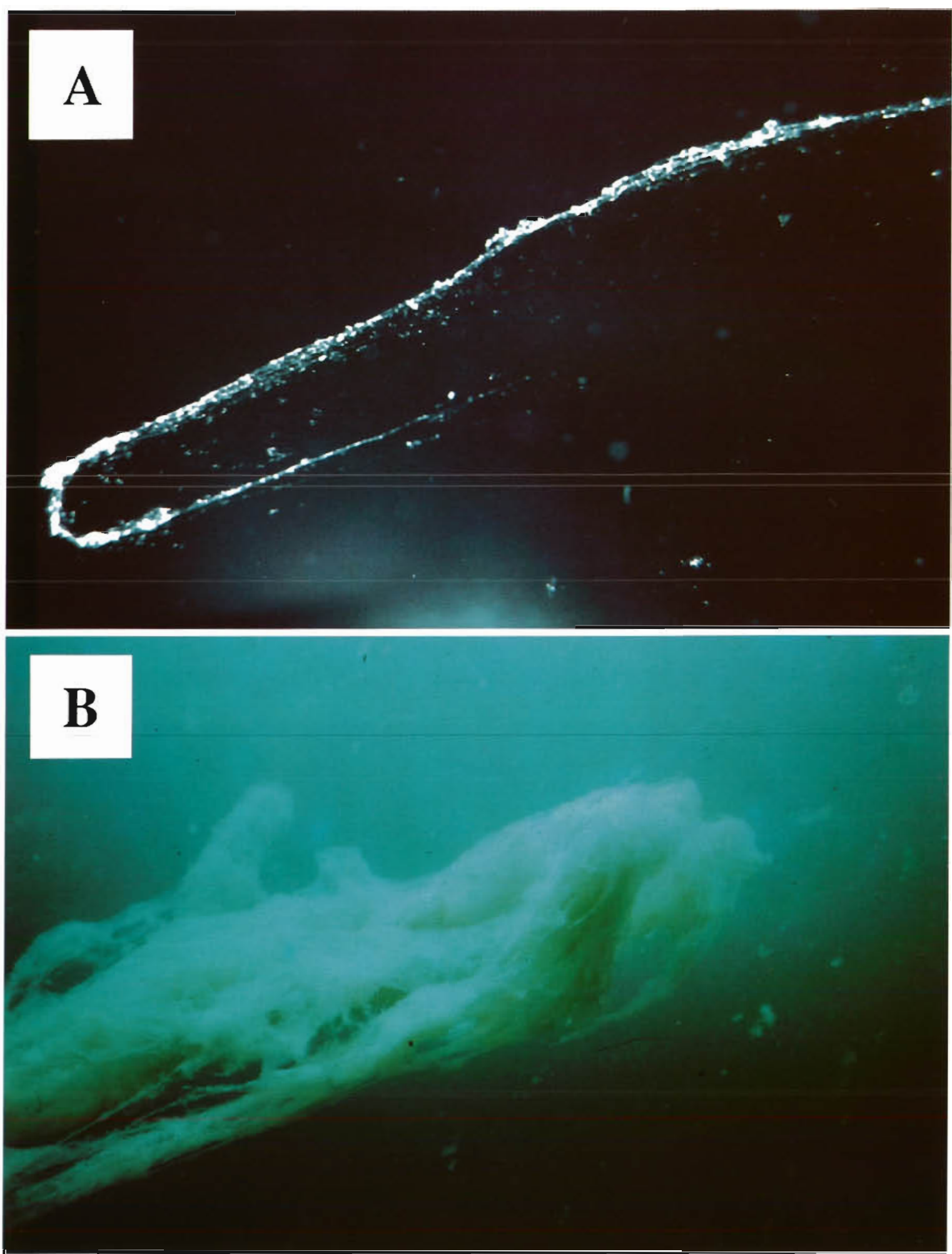

Fig. 2. (A) Stringer shaped marine snow in ca $8 \mathrm{~m}$ depth, length $5 \mathrm{~cm}$; component aggregates are $\leq 0.5 \mathrm{~cm}$. (B) $\mathrm{Cloud}$ in ca $22 \mathrm{~m}$ depth. Photographs taken 20 July 1989; length of cloud $3 \mathrm{~m}$ (courtesy of Andrej Jaklin, Center for Marine Research of the Ruder Boskovic Institute at Rovini, Croatia) 
noon $(10: 00$ to $14: 00 \mathrm{~h})$. In situ temperature regimes were maintained by a flow-through system which allows one to pump water from $3 \mathrm{~m}$ depth through the cores holding the incubation flasks. Surface irradiance as well as in situ irradiance conditions throughout the water column were regularly monitored. The incubations were ceased by placing the incubation flasks in a dark cooling box. The time between terminating the incubation and starting the filtration procedure was generally less than $5 \mathrm{~min}$. The incubated samples were filtered through Millipore HA filters $(47 \mathrm{~mm}$ filter diameter, $0.45 \mu \mathrm{m}$ pore size) and the filters were rinsed twice with $10 \mathrm{ml}$ of $0.2 \mu \mathrm{m}$ filtered seawater (Poretics polycarbonate filter, $47 \mathrm{~mm}$ filter diameter, $0.2 \mu \mathrm{m}$ pore size) from the sampling site. Thereafter the filters were fumed over concentrated $\mathrm{HCl}$ for $5 \mathrm{~min}$ and placed in scintillation vials, dried overnight and subsequently dissolved in $1 \mathrm{ml}$ ethylacetate (Riedel-de Haen); after $10 \mathrm{~min}, 8 \mathrm{ml}$ scintillation cocktail (Packard Insta-Gel) was added. After at least $12 \mathrm{~h}$ the scintillation vials containing the filters were placed in a liquid scintillation counter (Packard TriCarb) and counted. Quenching was corrected by external standard technique. Unless otherwise stated, data represent the integrated mean of the different irradiance levels used; primary production $\mathrm{d}^{-1}$ was calculated by assuming a $12 \mathrm{~h}$ production period. Hourly in situ irradiance measurements indicated that this assumption is reasonable.

Concurrently to the incubation of the radiolabeled samples in the outdoor incubator, unlabeled samples were incubated as well using the same type of vials (Winkler flasks for ambient water and glass scintillation vials for marine snow). These unlabeled samples were used for cyanobacterial enumeration before $\left(t_{0}\right)$ and after $\left(t_{1}\right)$ the incubation using epifluorescence microscopy as described above. The difference between $t_{0}$ and $t_{1}$ is thought to provide a minimum estimate of cyanobacterial production over the incubation period. The increase in cyanobacterial density was converted into cyanobacterial carbon production using the cell to carbon ratio obtained from the approach described above.

Chemical analyses. Alkaline phosphatase (APA) activity as an extracellular enzyme typical for phytoplankton was measured in samples of ambient water and marine snow in order to obtain another independent parameter of phytoplankton activity and to resolve the potential interdependence with phosphorus concentrations (Chrost \& Overbeck 1987). APA activity was measured as the increase in fluorescence when the nonfluorescing substrate methylumbelliferyl (MUF) phosphate (Sigma) is enzymatically hydrolized, releasing the highly fluorescent product methylumbelliferone (MU). A stock solution of $5 \mathrm{mM}$ was prepared with Methyl cellosolve (Sigma) and stored frozen $\left(-20^{\circ} \mathrm{C}\right)$. The MUF-phosphate stock solution was thawed and diluted with double-distilled water to obtain a $500 \mu \mathrm{M}$ solution. Diluted MUF-phosphate was added to $3 \mathrm{ml}$ of sample to obtain a final concentration of $2.5 \mu \mathrm{M}$. Incubations were performed in duplicate under in situ temperature conditions for 5 to $15 \mathrm{~min}$ depending on the activity. The increase in fluorescence of the samples was measured with a Jasco 820-FP spectrofluorometer at an emission wavelength of $440 \mathrm{~nm}$ and an excitation of $360 \mathrm{~nm}$. To convert the increase in fluorescence over time to the actual amount of MU released, subsamples were amended with $25 \mathrm{nM}$ of the fluorophore 4-methylumbelliferone (Sigma) dissolved in double-distilled water.

Inorganic nutrient concentrations were determined using routine methods (Parsons et al. 1984). Marine snow and clouds, however, had to be diluted 5 to 10 times with double-distilled water prior to analysis. Before measuring the absorbance in a Beckman DU-5 spectrophotometer the samples were filtered through Whatman GF/F glass fiber filters in order to remove any particles.

\section{RESULTS}

\section{General characteristics of mucoid aggregates}

Mucoid aggregates appeared after the decay of the spring phytoplankton and the onset of stratification. These small aggregates were of up to $0.5 \mathrm{~cm}$ in size (Fig. 2A) and neither enriched in inorganic nutrients or microbial biomass as compared to ambient water concentrations (authors' unpubl. data). In late May and early June heavy rain provoked an increased freshwater discharge, mainly via the River $\mathrm{Po}$, directly into the surface layers. This nutrient rich freshwater layer was ca $1.5 \mathrm{~m}$ thick and supported a massive cyanobacterial bloom in the surface layers of the entire Northern Adriatic Sea $2 \mathrm{~d}$ after this precipitation event. Probably due to reduced turbulence in the water column caused by stable weather conditions, marine snow continuously increased in size and a distinct layer was formed above the pycnocline. This spider-web-like 'false benthos' sensu Sieburth (1987) slowly moved towards the surface, most likely due to positive buoyancy as a result of gas entrapped in the mucoid matrix caused by microbial metabolism similar to the scenario proposed by Herndl et al. (in press). In 1991, marine snow aggregates increased in microbial parameters until the end of August when large (up to $5 \mathrm{~m}$ ) clouds were present in the water column (Fig. 2B). Throughout this paper marine snow is referred to as aggregations like the one presented in Fig. 2A, while the term 'cloud' is used for large aggregates such as shown in Fig. 2B (see also Stachowitsch et al. 1990). 
Table 1. Inorganic nutrient concentrations $(\mu \mathrm{M} ; \pm \mathrm{SD})$ in ambient water, marine snow and clouds

\begin{tabular}{|c|c|c|c|c|c|c|}
\hline & \multicolumn{2}{|c|}{ Ambient water } & \multicolumn{2}{|c|}{ Marine snow } & \multicolumn{2}{|c|}{ Clouds } \\
\hline & Conc. & $\mathrm{n}$ & Conc. & $\mathrm{n}$ & Conc. & $\mathrm{n}$ \\
\hline $\mathrm{NO}_{2}^{-}$ & $0.19 \pm 0.21$ & 26 & $0.66 \pm 1.60$ & 26 & $0.42 \pm 0.46$ & 7 \\
\hline $\mathrm{NO}_{3}^{-}$ & $1.56 \pm 1.91$ & 25 & $3.84 \pm 3.44$ & 24 & $1.94 \pm 1.29$ & 3 \\
\hline $\mathrm{NH}_{3}$ & $2.07 \pm 1.35$ & 26 & $4.03 \pm 4.38$ & 24 & $6.71 \pm 6.04$ & 3 \\
\hline$\Sigma N_{\text {inorg. }}$ & $3.87 \pm 2.83$ & 25 & $8.50 \pm 5.96$ & 23 & $9.16 \pm 6.49$ & 3 \\
\hline $\mathrm{PO}_{4}^{3-}$ & $0.10 \pm 0.19$ & 25 & $2.92 \pm 5.78$ & 25 & $5.20 \pm 7.87$ & 6 \\
\hline$\sum N_{\text {inorg. }} \mathrm{P}_{-} \mathrm{PO}_{4}{ }^{3-}$ & $69.73 \pm 58.26$ & 22 & $13.32 \pm 18.89$ & 22 & $9.43 \pm 8.30$ & 3 \\
\hline $\mathrm{NO}_{3}^{-}: \mathrm{NH}_{3}$ & $0.74 \pm 0.83$ & 25 & $1.95 \pm 2.33$ & 20 & $40.63 \pm 69.9$ & 3 \\
\hline
\end{tabular}

Development of inorganic nutrient concentrations in ambient water and mucoid aggregations

Inorganic nitrogen species did not follow a particular trend over the investigation period. Marine snow was found to be enriched in $\mathrm{NO}_{2}^{-}$by an enrichment factor (EF) of 3.5. $\mathrm{NO}_{3}{ }^{-}$by an EF of 2.5 and $\mathrm{NH}_{3}$ by a factor of 2; $\mathrm{PO}_{4}{ }^{3-}$ exhibited the highest EF (26.8) (Table 1). Clouds were less enriched in $\mathrm{NO}_{2}{ }^{-}$and $\mathrm{NO}_{3}{ }^{-}$(2.2 and 1.2 respectively); higher EFs were discernable, however, for $\mathrm{NH}_{3}$ and $\mathrm{PO}_{4}{ }^{3-}$ (3.2 and 47.7 respectively) (Table 1). Total inorganic nitrogen in ambient water amounted to $3.87 \mu \mathrm{g}$-at. $\mathrm{N}^{-1}, 8.5 \mu \mathrm{g}$-at. $\mathrm{N}^{-1}$ in marine snow and $9.16 \mu \mathrm{g}$-at. $\mathrm{N}^{-1}$ in clouds (Table 1). Over the investigation period, the ratio $\mathrm{NO}_{3}{ }^{-} / \mathrm{NH}_{3}$ declined significantly in ambient water as well as in marine snow (data not shown). The atomic ratio of $\mathrm{N}: \mathrm{P}$ deviated significantly from the Redfield ratio of 16 (Redfield et al. 1963) (Fig. 3A). While in ambient water mean N : P ratio was $69.7 \pm 58.3(n=22)$, this ratio decreased in marine snow to $13.3 \pm 18.9(\mathrm{n}=22)$ and in clouds to $9.4 \pm 8.4(n=3)$ (Fig. 3A).

While no consistent trend in the inorganic nitrogen species was discernable during the investigation period, orthophosphate declined in ambient waters ( $\mathrm{r}=0.644, \mathrm{n}=25, \mathrm{p}<0.001)$ while in marine snow ( $r=0.34, n=25, p<0.1)$ as well as in clouds ( $r=0.87$, $\mathrm{n}=5, \mathrm{p}<0.01) \mathrm{PO}_{4}{ }^{3-}$ concentrations increased significantly with time (Fig. 3B).

The autotrophic component with special reference to cyanobacteria

Chl a concentrations for ambient water, marine snow and clouds are shown in Fig. 4A. By the end of May, chl a concentrations of marine snow were within 1 order of magnitude of the values for ambient water. Within a few days after the cyanobacterial bloom started in early June, chl a concentrations increased in marine snow by 1 order of magnitude (to ca $2 \mu \mathrm{g}$ chl a $\left.\mathrm{l}^{-1}\right)$ while the ambient water chl a concentrations (in
$7 \mathrm{~m}$ to $10 \mathrm{~m}$ depth) remained nearly constant (ca 0.1 to $0.2 \mu \mathrm{g} \mathrm{chl} \mathrm{a} \mathrm{l}^{-1}$ ). Since the cyanobacterial bloom was confined to the superficial layers and the samples for chl a concentrations were taken from the same depth as marine snow, the bloom is not included in the ambient water values reported here; however, due to diel deviations in buoyancy of marine snow it is likely that marine snow rose into the surface layers thereby trapping cyanobacteria with the sticky matrix. This can explain
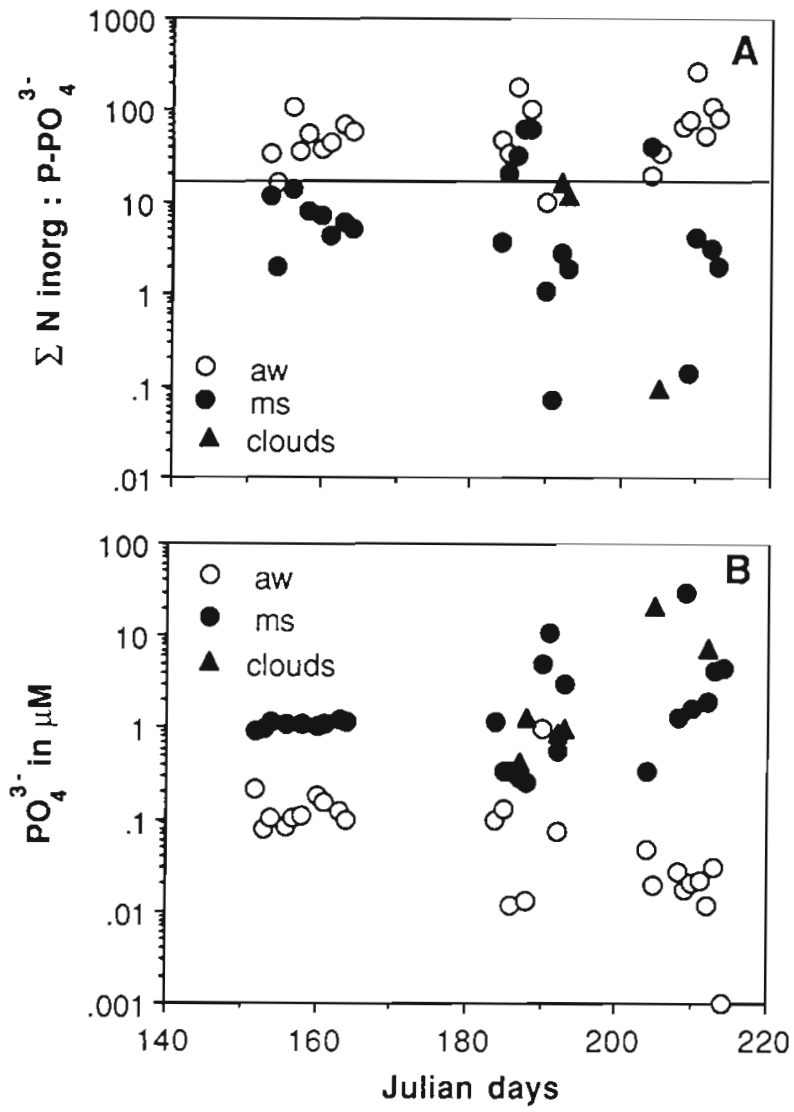

Fig. 3. Fluctuation of (A) the atomic ratio of $\left(\mathrm{N}-\mathrm{NO}_{3}{ }^{-}+\right.$ $\left.\mathrm{N}-\mathrm{NO}_{2}{ }^{-}+\mathrm{N}-\mathrm{NH}_{3}\right): \mathrm{P}^{-\mathrm{PO}_{4}{ }^{3-}}$ over the investigation period and (B) the concentration of $\mathrm{PO}_{4}{ }^{3-}$ in ambient water (aw), marine snow (ms) and clouds. The horizontal line in (A) indicates the Redfield ratio 

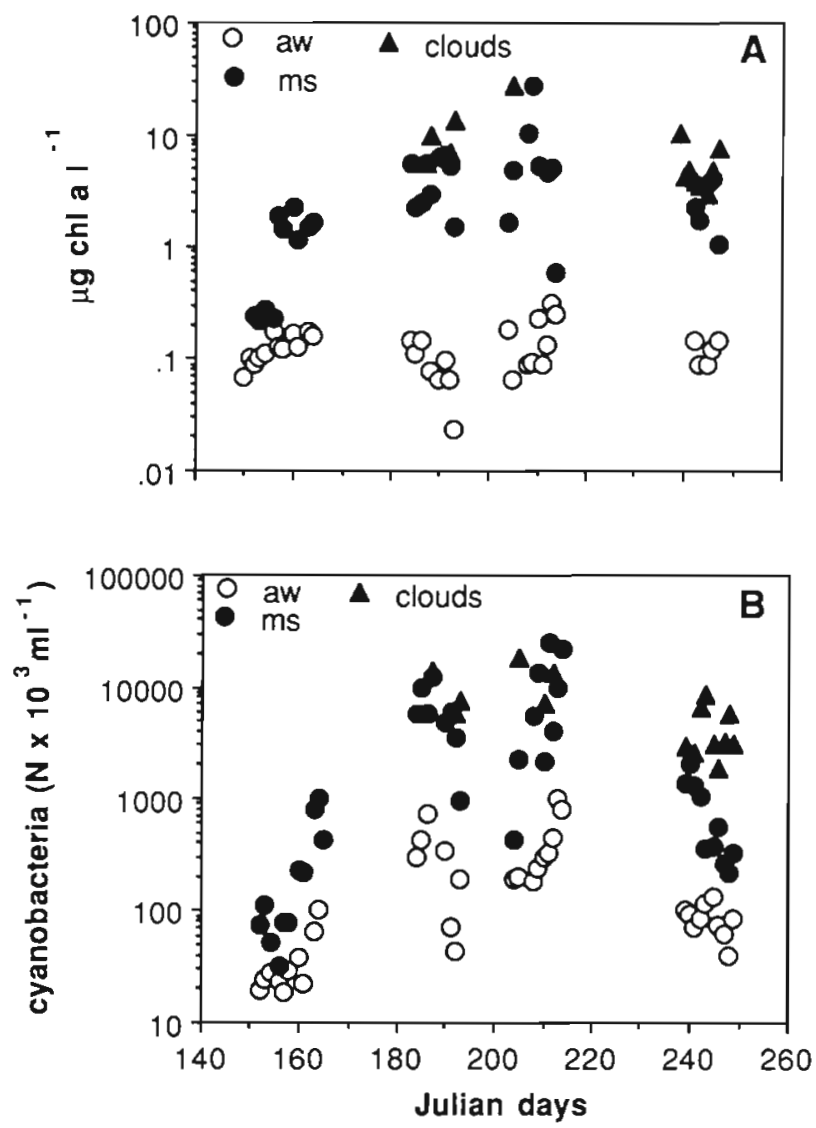

Fig. 4. Development of (A) chlorophyll a concentration and (B) cyanobacterial density during the investigation period; abbreviations as in Fig. 3

the rapid increase in chl a within a few days (Fig. 4A). The chl a concentration in clouds which appeared first in mid July was about 3 times higher than in marine snow. During the investigation period, mean ambient water concentrations in chl a were $0.13 \mu \mathrm{g} \mathrm{chl} \mathrm{a} \mathrm{l^{-1 }}$ (range: 0.02 to $0.31 \mu \mathrm{g} \mathrm{chl} \mathrm{a} \mathrm{l}^{-1}, \mathrm{n}=33$ ), mean concentrations in marine snow were $3.89 \mu \mathrm{g} \mathrm{chl} \mathrm{a} \mathrm{l}^{-1}$ (range: 0.22 to $27.88 \mu \mathrm{g} \mathrm{chl} \mathrm{ll}^{-1}, \mathrm{n}=31$ ) and the mean value for clouds was $9.51 \mu \mathrm{g} \mathrm{chl} \mathrm{a} \mathrm{l}^{-1}$ (range: 2.90 to $29.22 \mu \mathrm{g} \mathrm{chl}$ a $1^{-1}, \mathrm{n}=14$ ).

In ambient water, cyanobacteria increased in density from $20 \times 10^{3} \mathrm{ml}^{-1}$ by early June to about $500 \times 10^{3} \mathrm{ml}^{-1}$ in early July, declining thereafter to ca 50 to $80 \times 10^{3}$ $\mathrm{ml}^{-1}$ until September (Fig. 4B). In early June, cyanobacteria were found to be enriched in marine snow by an enrichment factor (EF) of ca 2 to 4 ; marine snow during July exhibited EF of up to 75 and cyanobacteria reached a mean density of $5.84 \times 10^{6}$ $\mathrm{ml}^{-1}$ marine snow (Fig. 4B). As was true for chl a concentrations, the highest values were found in clouds, reaching an EF of up to 130 and a cyanobacterial density of $24.9 \times 10^{6} \mathrm{ml}^{-1}$ (Fig. 4B). In late August and early September cyanobacterial density in clouds declined to densities only about 4 times the ambient water densities (ca 2 to $3 \times 10^{5} \mathrm{ml}^{-1}$ ).

The contribution of cyanobacteria to total chl a concentrations in ambient water as well as in marine snow was calculated from our measurements of chl a concentrations and TOC contents on a known amount of cyanobacterial cells which were grown on a modified $\mathrm{f} / 2$ medium. Based on our measurements we calculated a mean TOC content of a single cyanobacterial cell to amount to $48.85 \mathrm{fg} \mathrm{C}^{\mathrm{C}}$ cell ${ }^{-1}$ (range: 42.58 to $60.74, n=6$ ) and a mean $C:$ chl a ratio of 13.2 based on a chl a content of $3.69 \mathrm{fg}$ chl a cyanobacterium ${ }^{-1}$ (range: 2.83 to $4.98, \mathrm{n}=6$ ). As the cyanobacterial cultures were not axenic, bacterial carbon had to be subtracted from the TOC to obtain an estimate of the cyanobacterial carbon. Based on conversion factors given in the literature we estimated that about $34 \%$ of the biomass present in the culture was due to heterotrophic bacteria. Applying our conversion factors we calculated that cyanobacteria were the dominant autotrophic component in the ambient water as well as on mucoid aggregates throughout the investigation period, regardless of whether we used the more direct approach via chl a measurements or the indirect approach via conversion factors for carbon biomass. Calculated via chl a, cyanobacteria contributed on average about $75 \%$ to the total chl a concentration in ambient waters in June, in marine snow cyanobacterial contribution to chl a was slightly lower (ca 68\%) though not significantly so (Mann-Whitney, p > 0.2). Based on carbon, cyanobacteria made up $45.5 \%$ and $36.3 \%$ of the autotrophic biomass in ambient water and marine snow, respectively, in June. In July, the autotrophic biomass consisted almost exclusively of cyanobacteria contributing occasionally even more than $100 \%$ when calculated on the basis of chl a. In both ambient water and marine snow the \% contribution of cyanobacteria was higher when calculated on a chl a basis. The reasons for this will be discussed later (see 'Discussion').

Mean concentration of phaeopigments in ambient

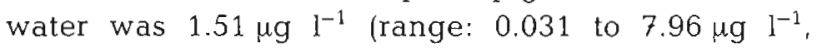
$\mathrm{n}=33$ ), in marine snow average phaeopigment concentration was $22.9 \mu \mathrm{g} \mathrm{l}^{-1}$ (range: 1.57 to $72.54 \mu \mathrm{g} \mathrm{l}^{-1}$, $\mathrm{n}=31$ ), and in clouds mean phaeopigment content was $29.24 \mu \mathrm{g} \mathrm{l}^{-1}$ (range: 12.28 to $62.48 \mu \mathrm{g} \mathrm{l}^{-1}, \mathrm{n}=13$ ). The ratio chl a:phaeopigments (chl a:phaeo) increased during the investigation periods in ambient water and in marine snow (Fig. 5); only in clouds did the chl a: phaeo ratio remain almost constant. This increase in the ratio especially at the end of our investigation period was due to the rapid decline of phaeopigment concentration in ambient water as well as in marine snow while chl a concentrations did not decline as rapidly (Fig. $4 \mathrm{~A}$ ). The chl a:phaeo ratio in ambient 


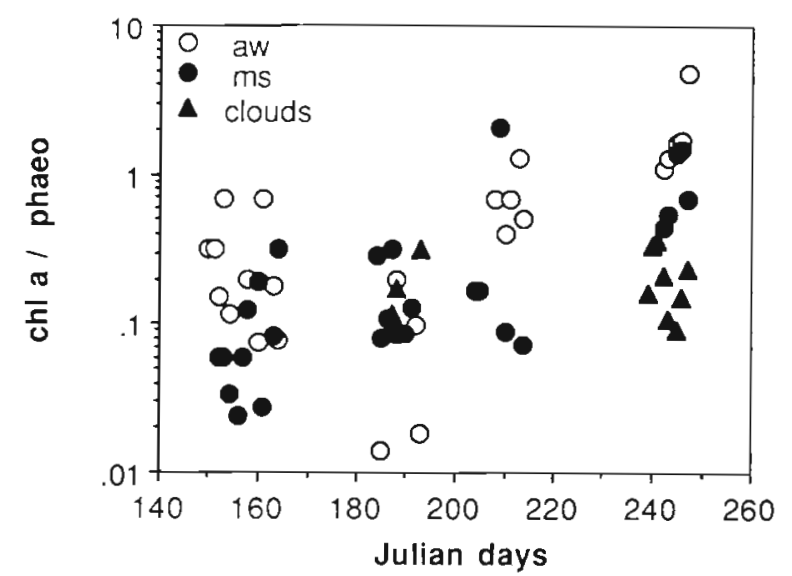

Fig. 5. Development of the chlorophyll a:phaeopigment ratio in ambient water (aw), marine snow (ms) and clouds during the investigation period

water was ca 2 times the ratio for marine snow; in clouds the ratio was 3.5 times lower than in ambient water.

Particulate primary production did not exhibit any particular trends over the investigation period. Mean primary production in ambient water was $1.07 \pm$ $0.7 \mu \mathrm{g} \mathrm{C} \mathrm{l}^{-1} \mathrm{~h}^{-1}$ (integrated mean over several irradiance levels per day, $16 \mathrm{~d}$ ), and particulate primary production in marine snow was about 10 times

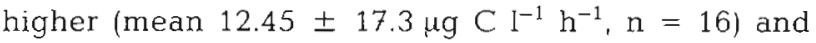
similar to the primary production in clouds. Primary production in marine snow was up to 1250 times higher than the corresponding values in ambient water. Specific productivity [in $\mu \mathrm{g} \mathrm{C} \mathrm{h}^{-1}(\mu \mathrm{g} \text { chl } a)^{-1}$ ] in ambient water as well as in marine snow decreased slightly though not significantly during the investigation period. Mean specific productivity in ambient water was $7.85 \pm 6.97 \mu \mathrm{g} \mathrm{C} \mathrm{h}{ }^{-1}(\mu \mathrm{g} \mathrm{chl} \mathrm{a})^{-1}(\mathrm{n}=44)$ while in marine snow it was only $3.56 \pm 4.5 \mu \mathrm{g} \mathrm{C} \mathrm{h}^{-1}$ $(\mu \mathrm{g} \mathrm{chl} a)^{-1}(\mathrm{n}=48)$; thus specific productivity in marine snow was significantly lower than in ambient water (dependent $t$-test, $t=5.716$, d.f. $=43, \mathrm{p}<0.001$ ). In clouds specific productivity was ca 1 order of magnitude lower than in ambient water $\left[0.7 \mu \mathrm{g} \mathrm{C} h^{-1}(\mu \mathrm{g} \mathrm{Chl}\right.$ a) ${ }^{-1}$ (range: 0.0 to $\left.1.43 \mu \mathrm{g} \mathrm{C} \mathrm{h}^{-1}(\mu \mathrm{g} \mathrm{chl} \mathrm{a})^{-1}\right), \mathrm{n}=3$ ]. Plotting primary production versus irradiance (P-I) levels indicated photoinhibition at an irradiance above $\mathrm{ca} 200 \mu \mathrm{E} \mathrm{m}^{-2} \mathrm{~s}^{-1}$ in ambient water and marine snow (Fig. 6).

Integrated over all irradiance levels, cyanobacterial production contributed to particulate primary production on average $15.9 \%$ (range: 0 to $73 \%$ ) in ambient water and $53.7 \%$ (range: 0 to $100 \%$ ) in marine snow. In ambient water, cyanobacteria contributed almost half of the primary production $(45.4 \%)$ at the lowest irradiance levels (10\% of surface irradiance) while in
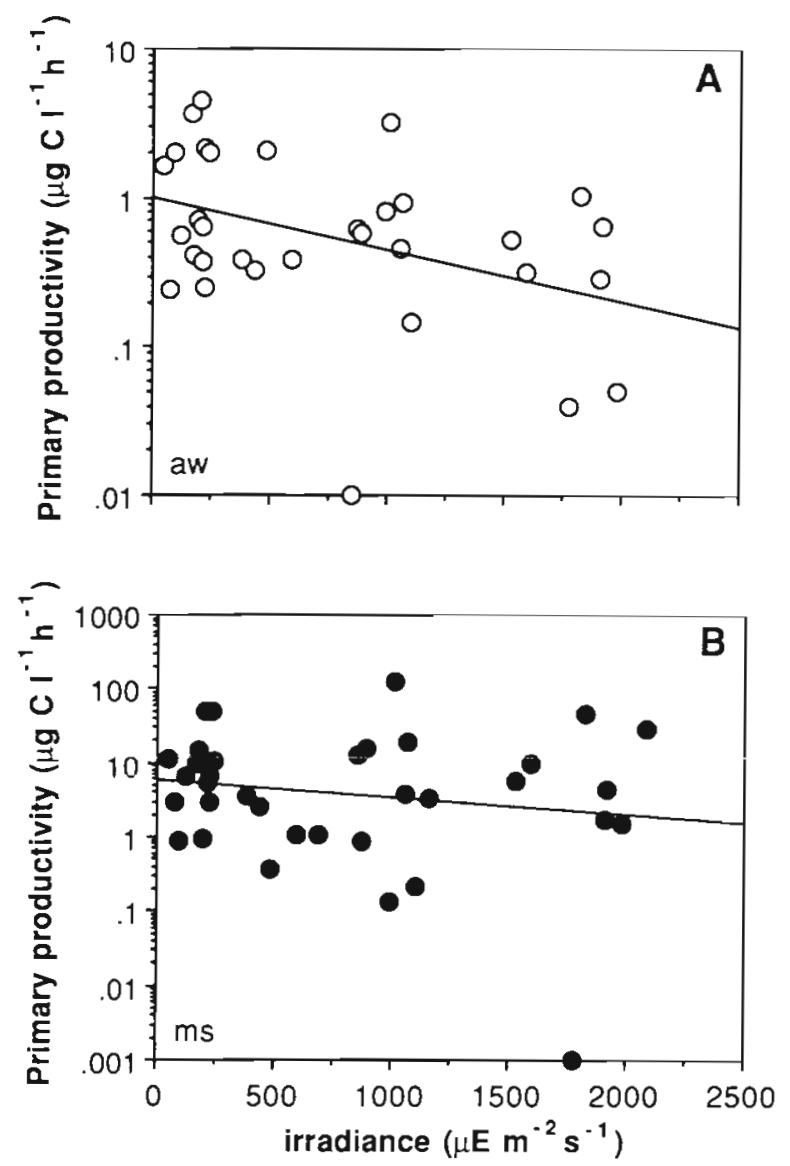

Fig. 6. Dependence of primary production on irradiance in (A) ambient water and (B) marine snow

marine snow the contribution was more or less stable regardless of the irradiance. Cyanobacterial production in marine snow was about 3.4 times higher than the corresponding production in ambient water.

While overall specific production was significantly higher in ambient water than in aggregates (see above), cyanobacterial specific production (calculated from the increase in cell numbers and using the factor given above to convert cell numbers to chl a equivalents) was significantly higher in marine snow (mean = $0.53 \pm 0.94 \mu \mathrm{g} \mathrm{C} \mathrm{h} \mathrm{h}^{-1}(\mu \mathrm{g} \text { cyanobacterial chl a })^{-1}(\mathrm{n}=$ 48)] than in ambient water [mean $=0.18 \pm 0.375 \mu \mathrm{g} \mathrm{C}$ $\mathrm{h}^{-1}$ ( $\mathrm{gg}$ cyanobacterial chl $\left.a\right)^{-1}(\mathrm{n}=48)$ l (dependent $t$-test, $t=2.893$, d.f. $=47, \mathrm{p}=0.006$ ). Total and cyanobacterial specific productivity versus irradiance revealed a generally lower specific productivity in cyanobacteria as compared to the productivity normalized to chl a concentrations in ambient waters. In ambient water, the photosynthetic yield in cyanobacteria decreased more dramatically with increasing irradiance than in the total phytoplankton community. In marine snow, however, this rapid decline in 
cyanobacterial specific productivity was not observed.

Mean alkaline phosphatase (APA) activity was found to be significantly higher (Wilcoxon, $p<0.0001$ ) in

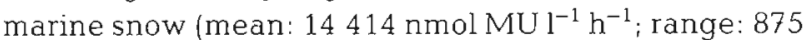

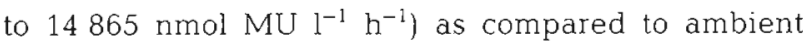

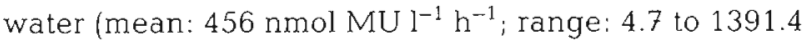
nmol MU l-1 $\mathrm{h}^{-1}$ ). As shown in Fig. $7 \mathrm{~A}$, APA activity in ambient waters declined exponentially during summer 1991 while in marine snow as well as in clouds APA activity increased until Julian Day 210; thereafter APA activity declined slightly. This increase in APA activity in marine snow and the concurrent decline in the respective activity in ambient waters is reflected by the highly significant increase in the EF of APA activity over time (Fig, 7 B). The high APA activity in marine snow and clouds can be explained by the higher chl a concentration (Fig. 7C); APA activity per units chl a is not significantly higher in marine snow (dependent $t$ test, d.f. $=23 ; t=1.643 ; \mathrm{p}=0.114$ ). Fig. $7 \mathrm{D}$ shows that APA activity per unit chl $a$ is not correlated with the end-product concentration of the enzyme reaction - the $\mathrm{PO}_{4}{ }^{3-}$ concentration.
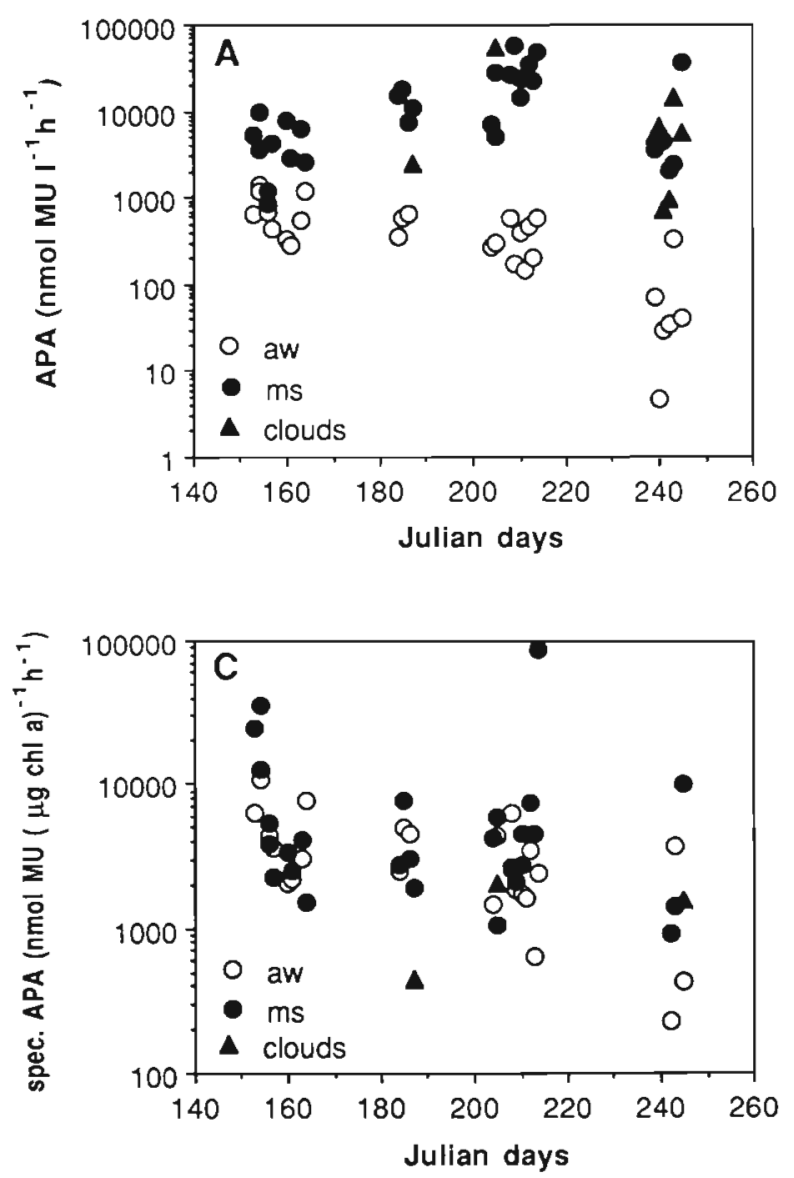

\section{DISCUSSION}

Surface floating mucilage in the Northern Adriatic Sea has been known to occur occasionally during calm weather conditions for more than a century (Marchetti 1990). Only recently, however, has the likely source of these floating surface scums - giant mucoid aggregations - been described (Herndl 1988, Herndl \& Peduzzi 1988, Puskaric et al. 1992); these authors emphasize the importance of the pycnocline layer in the formation of large aggregations since near-laminar flow is prevailing close to the pycnocline facilitating aggregation of mucoid material (Jenkinson 1989, 1990). This sticky material efficiently traps particles from the pelagic environment. Thus, prolonged residence time of these aggregates in the water column provokes a continuous enrichment in microbial biomass as shown for phytoplankton including cyanobacteria (Fig. 4). These aggregates are, however, not only prevented from sinking due to the pycnocline but they are also confined to the water masses of the Northern Adriatic Sea, as circular counterclockwise currents during summer
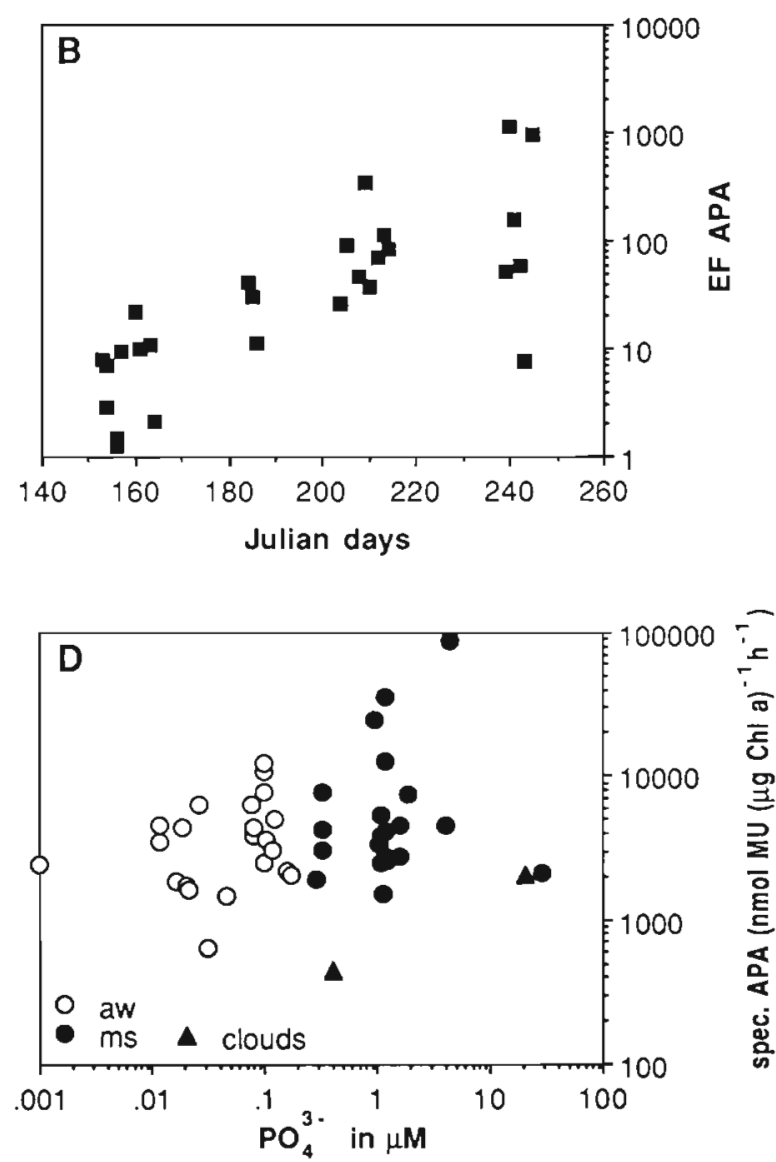

Fig. 7. Development of (A) alkaline phosphatase (APA) activity, $(B)$ enrichment over ambient water activity $\left(E F=A P A_{m s} / A P A_{a w}\right)$ and (C) specific APA activity in ambient water (aw), marine snow (ms) and clouds during the investigation period. (D) Relation between $\mathrm{PO}_{4}{ }^{3-}$ concentrations and specific APA activity 
separate these water masses from the remaining Adriatic waters (Oric 1987).

The initial stage of marine snow is characterized by EFs of around 1, indicating that marine snow was neither enriched in nutrients or planktonic organisms at that time; a consecutive increase, however, in phytoplankton biomass (measured as chl a) and cyanobacterial biomass was detectable until early August (Julian Day 210) (Figs. 4 \& 5). Thereafter marine snow showed signs of senescence as indicated by lower chl a:phaeopigment ratios than in the ambient water (Fig. 5). This senescent stage is even more evident in the clouds where chl a:phaeopigment ratios were more than 1 order of magnitude lower than in ambient water. As these clouds appeared only about 1 mo after the increase in marine snow attached microbial biomass, we tentatively assume that these large clouds are typical formations of senescent marine snow. Increasing $\mathrm{C}$ : $\mathrm{N}$ ratios in clouds and the data presented by Posedel \& Faganeli (1991) further support this assumption (Müller-Niklas \& Herndl unpubl.). In their mature stage these clouds are anoxic in their center and are highly enriched in sulfide; $\mathrm{H}_{2} \mathrm{~S}$ concentrations in the $\mathrm{mM}$ range were detectable (authors' unpubl. data).

EFs reported in this paper are within the range given in the literature despite the larger size of the aggregates in the Northern Adriatic Sea (Alldredge \& Silver 1988); Alldredge \& Gotschalk (1990) have shown that the EF in nutrients and/or biomass is directly related to the origin of the marine snow; phytoplankton-derived marine snow exhibits the highest EFs. The origin of marine snow in the Northern Adriatic Sea may vary; whenever large masses of marine snow appear, however, they are most likely of phytoplankton origin as indicated by a similar carbohydrate composition of the mucoid matrix of the aggregations and of cultured phytoplankton (Posedel \& Faganeli 1991).

The increase in phytoplankton biomass was not accompanied by a comparable increase in the concentration of inorganic nutrients (Table 1); there is, however, a detectable tendency towards an increasing importance of ammonia as nitrogen source for phytoplankton production in marine snow as well as in ambient water, as the ratio of $\mathrm{NO}_{3}{ }^{-}: \mathrm{NH}_{3}$ decreased during the investigation period. Fig. 8 indicates a relation between phytoplankton biomass (in terms of chl a) and the $\Sigma N: P$ ratio. At low chl a levels the $\Sigma N: P$ ratio was well above the Redfield ratio while at the high chl a concentrations typical for marine snow the $\Sigma N$ : $P$ ratio is below 16. Thus the inorganic nutrient conditions in marine snow and clouds are relatively close to the Redfield ratio, and primary production might be only occasionally limited in nitrogen while ambient water primary production is obviously severely limited in phosphorus. This severe phosphorus limitation could also be responsible for enhanced mucus production by the phytoplankton in the ambient water (Fogg 1983). Kaltenböck \& Herndl (unpubl.) obtained under phosphorus limited conditions a photosynthetically extracellular release (PER) of $80 \%$ for the phytoplankton in the ambient water while marine snow associated phytoplankton exhibited a PER of only $30 \%$. There is evidence that 'mucilage production represents an overflow taking place when photosynthesis is possible but nutrient limitation or other inhibiting circumstances retards uptake of its products in growth of cell material' (Fogg 1990). Therefore, one might expect that in ambient waters, phytoplankton exhibits higher APA activity per chl a to overcome the apparent phosphorus limitation, which is, however, not the case as shown in Fig. 7D.

Mean growth rate of phytoplankton in ambient waters was $3.35 \mathrm{~d}^{-1}$ while in marine snow and clouds growth rates were considerably lower $\left(1.28\right.$ and $0.3 \mathrm{~d}^{-1}$ respectively). Similar growth rates have been reported from other neritic environments as well (Laws et al. 1984, Booth et al. 1988). These differences in the estimated growth rates between ambient water and the mucoid aggregates could also potentially result from incomplete ciffusion into the mucoid matrix of the label added; attention has been paid, however, to ensure mixing of the $1 \mathrm{ml}$ of tracer in the $20 \mathrm{ml}$ scintillation vials in which primary production measurements of the mucoid aggregates were performed. Although we cannot rule out incomplete mixing of the tracer it is unlikely that this is responsible for the observed differences in phytoplankton growth rates. Growth rates of cyanobacteria as calculated from the increase in cell density over time are significantly higher in marine snow (mean $=0.413 \pm 0.782 \mathrm{~d}^{-1}, \mathrm{n}=28$ ) (Wilcoxon,

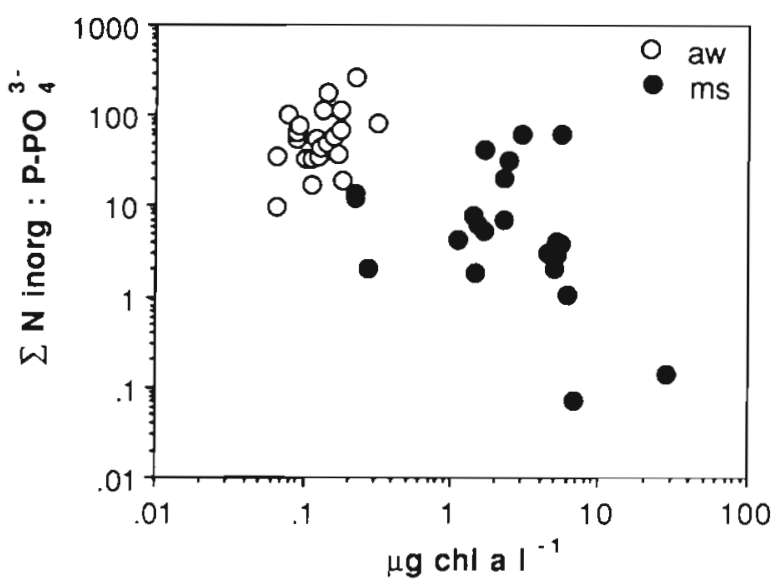

Fig. 8. Relation between chlorophyll a concentration and atomic ratio of $\left(\mathrm{N}_{-} \mathrm{NO}_{3}{ }^{-}+\mathrm{N}-\mathrm{NO}_{2}{ }^{-}+\mathrm{N}-\mathrm{NH}_{3}\right): \mathrm{P}^{-} \mathrm{PO}_{4}{ }^{3-}$ in ambient water (aw) and marine snow (ms) 
$\mathrm{p}<0.01$ ) than in ambient water (mean $=0.14 \pm 0.26$ $\mathrm{d}^{-1}, \mathrm{n}=28$ ). These growth rates for cyanobacteria are within the range $\left(0.1\right.$ to $\left.0.9 \mathrm{~d}^{-1}\right)$ reported for Synechococcus $\mathrm{sp}$. in coastal marine and freshwater environments (Jochem 1988, Vernet et al. 1990, Fahnenstiel \& Carrick 1991, Kuosa 1991). Potentially, cyanobacterial production in ambient water could be underestimated to a higher degree than in marine snow as higher grazing losses might be expected for the free-living cyanobacterial community as compared to marine snow where cyanobacteria are embedded in an organic matrix.

Based on the estimated average primary production rates in terms of carbon we may calculate the turnover rates of the inorganic nitrogen and phosphorus pools in ambient water und marine snow, respectively, assuming an atomic C:N:P ratio of 106:16:1 (Redfield et al. 1963). Given a mean primary production (PP) rate in ambient water of $12.8 \mu \mathrm{g} \mathrm{C} \mathrm{l}^{-1} \mathrm{~d}^{-1}$, in marine snow of $149.3 \mu \mathrm{g} \mathrm{Cl}^{-1} \mathrm{~d}^{-1}$, and in clouds of $85.1 \mu \mathrm{g} \mathrm{C} \mathrm{l}^{-1} \mathrm{~d}^{-1}$ we arrive at a nitrogen demand of $1.9,22.5$ and $12.8 \mu \mathrm{g} \mathrm{N}$ $\mathrm{l}^{-1} \mathrm{~d}^{-1}$ respectively; the respective $\mathrm{P}$ demands are 0.12 , 1.4 and $0.8 \mu \mathrm{g} \mathrm{P}^{-1} \mathrm{~d}^{-1}$. Dividing these rates with the respective mean inorganic nitrogen and phosphorus concentrations given in Table 1 we calculate $\mathrm{N}$ turnover rates of $0.5,2.7$ and $1.4 \mathrm{~d}^{-1}$ respectively; similarly, $P$ turnover rates are $1.1,0.5$ and $0.2 \mathrm{~d}^{-1}$ for ambient water, marine snow and clouds. These values are maximum estimates as in the calculations of the turnover rate only the inorganic nutrient sources are considered to be available for the autotrophs, which most likely does not hold true (Price et al. 1985, Mitamura \& Saijo 1986, Sahlsten 1987, Price \& Morel 1991). These turnover rates indicate the difference between $N$ und $P$ cycling; while inorganic nitrogen is turned over 5 times faster in marine snow than in ambient water, inorganic phosphorus is turned over about twice as fast in ambient water.

In the present study, cyanobacteria made up a considerable portion of autotrophic planktonic biomass (on the basis of chl a: $75 \%$ in ambient waters and $68 \%$ in marine snow). These values are in the upper range of values reported for temperate and boreal seas and correspond more to values reported from the warm tropical and subtropical waters (Joint \& Pomeroy 1983, Iturriaga \& Marra 1988, Jochem 1988, Kuosa 1991). The discrepancy between the contribution of cyanobacteria calculated on the basis of chl a versus carbon content of cyanobacteria (see 'Results') stems most likely from the difficulty in filtering marine snow onto the Whatman $\mathrm{GF} / \mathrm{F}$ filters which were used for chl a determinations. This mucoid material easily clogs the filter, resulting in a longer filtration time and most likely in a more pronounced degradation of chl a as described by Stramski (1990).
Our factors to convert cyanobacterial cell densities into chl a concentrations and carbon equivalents of

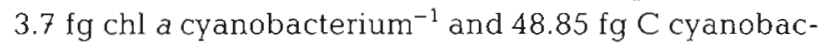
terium $^{-1}$ are similar to those reported by Joint \& Pomeroy (1986), who obtained a chl a concentration of $1.8 \mathrm{fg}_{\text {cyanobacterium }}-1$ and a mean carbon content of $53 \mathrm{fg}$ cyanobacterium $^{-1}$, but considerably lower than the carbon ratio reported by Kana \& Gilbert (1987), who obtained $250 \mathrm{fg} C$ cyanobacterium ${ }^{-1}$.

Primary production in marine snow correlated fairly well with ambient water primary productivity (Fig. 9), indicating that marine snow attached phytoplankton is probably derived to a large extent by random collision of phytoplankton with the mucoid aggregates. Overall primary production in marine snow was about 10 times higher than in ambient waters while chl a specific primary production in ambient water was found to be twice the value as obtained for marine snow [3.56 $\mu \mathrm{g} \mathrm{C}$

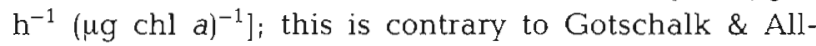
dredge (1989), who detected 2 to 9 times higher specific productivity in marine snow of diatom origin. Cyanobacterial specific productivity, however, was found to be significantly higher in marine snow than in ambient water. The maximum production $\left(\mathrm{P}_{\max }\right)$ values we obtained for cyanobacteria ranged from 0.9 to $3.6 \mathrm{fg}$ $\mathrm{C}$ cell ${ }^{-1} \mathrm{~h}^{-1}$ in ambient water and in marine snow from 1.9 to $10.8 \mathrm{fg} \mathrm{C} \mathrm{cell}^{-1} \mathrm{~h}^{-1}$. $\mathrm{P}_{\max }$ for Synechococcus spp. from marine environments ranges from 2 to 40 (Prezelin et al. 1986, 1987, Iturriaga \& Marra 1988). Therefore our values are at the lower end of those reported in the literature except for Fahnenstiel \& Carrick (1991), who give a range in $\mathrm{P}_{\max }$ of 1.9 to $6.0 \mathrm{fg} \mathrm{C} \mathrm{Cell}^{-1} \mathrm{~h}^{-1}$ for Lakes Huron and Michigan.

Cyanobacteria contributed $16 \%$ to overall primary production in ambient water and on average $54 \%$ in marine snow, pointing to the importance of cyanobacteria to overall production in marine snow during the

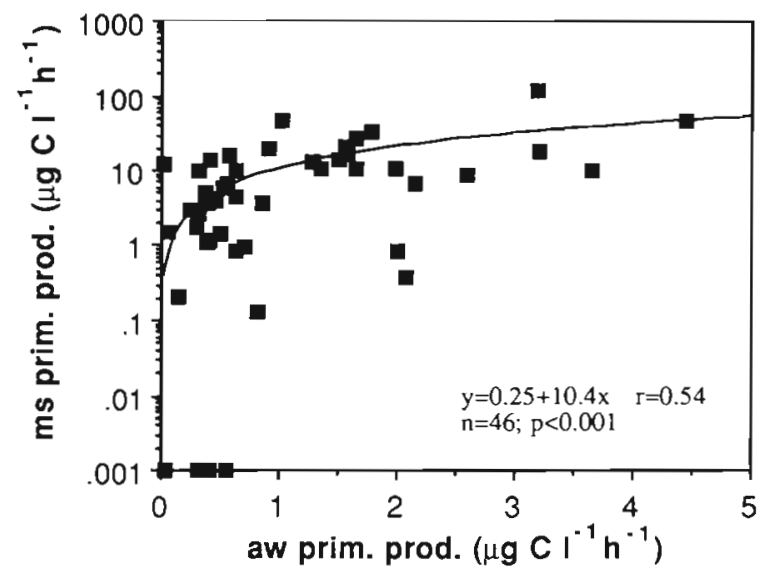

Fig. 9. Relation between ambient water primary production (aw prim. prod.) and marine snow primary production (ms prim. prod.) 
investigation period. It should be noted in this respect that in 1991 the marine snow appeared to be different from those aggregates detected in previous years which were produced primarily by diatoms and flagellates (Revelante \& Gilmartin 1991). The contribution of marine snow primary production to overall primary productivity of the water column in the Northern Adriatic Sea might be estimated assuming a ca $5 \%$ contribution of marine snow to total volume of the water column during the investigation period (Herndl unpubl). Given a water column depth typical for the Northern Adriatic Sea of $20 \mathrm{~m}$ and a depth integrated mean primary production in the ambient water and marine snow of 1.07 and $12.45 \mathrm{mg} \mathrm{C} \mathrm{m}^{-3} \mathrm{~h}^{-1}$, respectively, we arrive at an overall ambient water primary production of $1.07 \times 19 \mathrm{~m}^{3}=20.33 \mathrm{mg} \mathrm{C} \mathrm{m} \mathrm{m}^{-2} \mathrm{~h}^{-1}$; for marine snow the corresponding production rate is $12.45 \times 1 \mathrm{~m}^{3}(5 \%$ of a $20 \mathrm{~m}$ deep water column $)=$ $12.45 \mathrm{mg} \mathrm{C} \mathrm{m} \mathrm{C} \mathrm{h}^{-1}$. Thus total primary production of the water column amounts to $32.78 \mathrm{mg} \mathrm{C} \mathrm{m}^{-2} \mathrm{~h}^{-1}, 38 \%$ of which is associated with marine snow. This contribution of marine snow to overall primary productivity is lower than the percentage reported earlier for the same area (Herndl 1988). In the previous report, however, the autotrophic component of marine snow was primarily composed of diatoms. High production rates and enrichment factors in diatom based marine snow have also been reported by Alldredge \& Gotschalk (1990).

In this paper we have shown that cyanobacterial blooms in temperate waters eventually lead to a continued growth on mucoid matrices when they are present in the water column. Once cyanobacteria are colonizing these matrices they respond with enhanced growth rates, further fueling the mucoid matter pool and thus supporting further aggregation of marine snow in conjunction with low turbulence of the water column. Cyanobacteria based marine snow underlies successional changes in nutrient and biomass concentrations as well as in primary production as marine snow ages.

Acknowledgements. We are deeply indebted to S. FondaUmani, L. Talarico and G. Honsell for collaborative work and for sharing lab space with us. We gratefully acknowledge the help of R. Amon, A. Bochdansky, M. Karner, G. MüllerNiklas during field work and the Laboratorio di Biologia Marine Trieste-Auarisina (Italy) for their hospitality, and thank J. A. Ott for his continuous interest in the work and for critically reading a former draft of the manuscript. This study was supported by the Austrian Science Foundation (FWF) grant \# P 7748-BIO (to G.J.H) and the Alpe-Adria campaign on the Reasons and Consequences of the Occurrence of Gelatinous Aggregations in the Northern Adriatic Sea' (Osservatorioo dell'Alto Adriatico). This work is in partial fulfiltment of the requirements for a M.Sc. degree from the Lniversity of Vienna by E.K.

\section{LITERATURE CITED}

Alldredge, A. L., Gotschalk, C. C. (1990). The relative contribution of marine snow of different origins to biological processes in coastal waters. Cont. Shelf Res. 10:41-58

Alldredge, A., Granata, T C., Gotschalk, C. C., Dickey, T. D. (1990). The physical strength of marine snow and its implications for particle disaggregation in the ocean. Limnol. Oceanogr. 35: 1415-1428

Alldredge, A. L., McGillivary, P. (1991). The attachment probabilities of marine snow and their implications for particle coagulation in the ocean. Deep Sea Res. 38: 431-443

Alldredge, A. L., Silver, M. W (1988). Characteristics, dynamics and significance of marine snow. Prog. Oceanogr. 20: 41-82

Booth, B. C., Lewin, J., Lorenzen, C. J. (1988). Spring and summer growth rates of subarctic Pacific phytoplankton assemblages determined from carbon uptake and cell volumes estimated using epifluorescence microscopy. Mar. Biol. 98: 287-298

Chrost, R. J., Overbeck, J. (1987). Kinetics of alkaline phosphatase activity and phosphorus availability for phytoplankton and bacterioplankton in Lake Plußsee (North German eutrophic lake). Microb. Ecol. 13: 229-248

Fahnenstiel, G. L., Carrick, H. J. (1991). Physiological characteristics and food-web dynamics of Synechococcus in Lakes Huron and Michigan. Limnol. Oceanogr. 36 $219-234$

Fogg, G. E. (1983). The ecological significance of extracellular products of phytoplankton photosynthesis. Botanica mar 26: $3-14$

Fogg, G. E. (1990). Massive phytoplankton gel production. In: Barth, H., Fegan, L. (eds.) Eutrophication-related phenomena in the Adriatic Sea and other Mediterranean coastal zones. Water pollution research report 16. Commission of the European Communities, Brussels, p. 207-212

Gotschalk, C. C., Alldredge, A. L. (1989). Enhanced primary production and nutrient regeneration within aggregated marine diatoms. Mar. Biol. 103: 119-129

Herndl, G. J. (1988). Ecology of amorphous aggregations (marine snow) in the Northern Adriatic Sea. II. Microbial density and activity in marine snow and its implication to overall pelagic processes. Mar. Ecol. Prog. Ser. 48: $265-275$

Herndl, G. J., Karner, M., Peduzzi, P. (in press). Floating mucilage in the Northern Adriatic Sea: the potential of a microbial ecological approach to solve the 'mystery'. Sci. total Environ.

Herndl, G. J., Peduzzi, P. (1988). Ecology of amorphous aggregations (marine snow) in the Northern Adriatic Sea: I. General considerations. P.S.Z.N.I. Mar. Ecol. 9: 79-90

Howard, K. M., Joint, I. R. (1989). Physiological ecology of picoplankton in the North Sea. Mar. Biol. 102: 275-281

Iturriaga, R., Marra, J. (1988). Temporal and spatial variability of chroococcoid cyanobacteria Synechococcus spp. specific growth rates and their contribution to primary production in the Sargasso Sea. Mar. Ecol. Prog. Ser. 44: $175-181$

Jenkinson, I. R. (1989). Ecological implications of sheardependent viscosity found in the sea. In. Klekowski, R. Z., Styczynska-Jurewricz, E., Falkowski, L. (eds.) Proc. 21st Eur. Mar Biol. Symp. Ossolineum, Gdansk, p. 121-130

Jenkinson, I. R. (1990). Rheological structure in bulk seawater In: Oliver, D. R. (ed.) Third European Rheology Conference and Golden Jubilee Meeting of the British Society of Rheology. Elsevier Applied Science, London, p. 28-36

Jochem, F. (1988). On the distribution and importance of 
picocyanobacteria in a boreal inshore area (Kiel Bight, Western Baltic). J. Plankton Res. 10: 1009-1022

Jochem, F. (1989). Distribution and importance of autotrophic ultraplankton in a boreal inshore area (Kiel Bight, Western Baltic). Mar Ecol. Prog. Ser. 53: 153-168

Joint, I. R., Pomeroy, A. J. (1983). Production of picoplankton and small nanoplankton in the Celtic Sea. Mar Biol. 77 : $19-27$

Joint, I. R., Pomroy, A. J. (1986). Photosynthetic characteristics of nanoplankton and picoplankton from the surface mixed layer. Mar. Biol. 92: 465-474

Kana, T M., Glibert, P. M. (1987). Effect of irradiances up to $2000 \mu \mathrm{E} \mathrm{m}^{-2} \mathrm{~s}^{-1}$ on marine Synechococcus WH7803-I. Growth, pigmentation, and cell composition. Deep Sea Res. 34: 479-495

Kuosa, H. (1991). Picoplankton algae in the northern Baltic Sea: seasonal dynamics and flagellate grazing. Mar. Biol. 73: $269-276$

Lancelot, C. (1983). Factors affecting phytoplankton extracellular release in the Southern Bight of the North Sea. Mar. Ecol. Prog. Ser. 12: 115-121

Laws, E. A., Redalje, D. G., Haas, L. W., Bienfang, P. K. Eppley, R. W., Harrison, W. G., Karl, D. M., Marra, J. (1984). High phytoplankton growth rates in oligotrophic Hawaiian coastal waters. Limnol. Oceanogr. 29: $1161-1169$

Lee, S., Fuhrman, J. A. (1987). Relationships between biovolume and biomass of naturally derived marine bacterioplankton. Appl. environ. Microbiol. 53: 1298-1303

Li, W. K. W., Platt, T. (1987). Photosynthetic picoplankton in the ocean. Sci. Prog., Oxf. 71. 117-132

Marchetti, R. (1990). Algal blooms and gel production in the Adriatic Sea. In: Barth, H. Fegan, L. (eds.) Eutrophicationrelated phenomena in the Adriatic Sea and in other Mediterranean coastal zones. Commission of the European Communities, Brussels, p. 21-42

Mitamura, O., Saijo, Y. (1986). Urea metabolism and its significance in the nitrogen cycle in the euphotic layer of lake Biwa. I. In situ measurement of nitrogen assimilation and urea decomposition. Arch. Hydrobiol. 107: 23-51

Orlic M. (1987). Oscillations of the inertia period on the Adriatic Sea shelf. Cont. Shelf Res. 7: 577-598

Orlic, M., Kuzmic, M., Vucak, Z. (1986). Wind-curl currents in the Northern Adriatic and formulation of bottom friction. Oceanol. Acta 9: 425-431

Parsons, T., Maita, Y., Lalli, C. (1984). A manual of chemical and biological methods for seawater analysis. Pergamon Press, Oxford

Porter, K. G., Feig, Y. S. (1980). The use of DAPI for identifying and counting aquatic microflora. Limnol. Oceanogr. 25: 943-948

Posedel, N., Faganeli, J. (1991). Nature and sedimentation of suspended particulate matter during density stratification in shallow coastal waters (Gulf of Trieste, northern Adriatic). Mar. Ecol. Prog. Ser. 77: 135-145

This article was submitted to the editor
Prezelin, B. B., Glover, H. E., Campbell, L. (1987). Effects of light intensity and nutrient availability on diel patterns of cell metabolism and growth in populations of Synechococcus spp. Mar. Biol. 95: 469-480

Prezelin, B. B., Putt, M., Glover, H. E. (1986). Diurnal patterns in photosynthetic capacity and depth-dependent photosynthesis-irradiance relationships in Synechococcus spp. and larger phytoplankton in three water masses in the Northwest Atlantic Ocean. Mar. Biol. 91. 205-217

Price, N. M., Cochlan, W. P., Harrison, P. J. (1985). Time course of uptake of inorganic and organic nitrogen by phytoplankton in the Strait of Georgia: comparison of frontal and stratified communities. Mar. Ecol. Prog. Ser 27: $39-53$

Price, N. M., Morel, F. M. M. (1991). Colimitation of phytoplankton growth by nickel and nitrogen. Limnol. Oceanogr. 36: 1071-1077

Puskaric, S., Fowler, S. W., Miquel, J. C. (1992). Temporal changes in particulate flux in the Northern Adriatic Sea. Estuar. coast. Shelf Sci. (in press)

Redfield, A. C., Ketchum, B. H., Richards, F. A. (1963). The influence of organisms on the composition of sea water. In: Hill, M. N. (ed.) The sea. Wiley, New York, p. 26-77

Revelante, N., Gilmartin, M. (1991). The phytoplankton composition and population enrichment in gelatinous 'macroaggregates' in the Northern Adriatic during the summer of 1989. J. exp. mar. Biol. Ecol. 146: 217-233

Sahlsten, E. (1987). Nitrogenous nutrition in the euphotic zone of the Central North Pacific Gyre. Mar Biol. 96: 433-439

Sieburth, J. M. (1987). Contrary habitats for redox-specific processes: methanogenesis in oxic waters and oxidation in anoxic waters. In: Sleigh, M. A. (ed.) Microbes in the sea. Halsted Press, Chichester, p. 11-38

Sommer, U. (1989). Toward a Darwinian ecology of plankton. In: Sommer, U. (ed.) Plankton ecology, Succession in plankton communities. Springer, Heidelberg, p. 1-8

Stachowitsch, M., Fanuko, N., Richter, M. (1990). Mucus aggregates in the Adriatic Sea: an overview of stages and occurrences. P.S.Z.N.I. Mar Ecol. 11: 327-350

Stockner, J. G. (1988). Phototrophic picoplankton: an overview from marine and freshwater ecosystems. Limnol. Oceanogr. 33: 765-775

Stramski, D. (1990). Artifacts in measuring absorption spectra of phytoplankton collected on a filter. Limnol. Oceanogr. 35: $1804-1809$

Vernet, M., Mitchell, B. G., Holm-Hansen, O. (1990). Adaptation of Synechococcus in situ determined by variability in intracellular phycoerythrin-543 at a coastal station off the Southern California coast, USA. Mar. Ecol. Prog. Ser. 63: 9-16

Waterbury, J. B., Watson, S. W. Valois, F. W., Franks, D. G. (1986). Biological and ecological characterization of the marine unicellular cyanobacterium Synechococcus. In: Platt, T., Li, W. K. W (eds.) Photosynthetic picoplankton. Can. Bull. Fish. Aquat. Sci., Toronto, p. 71-120

Manuscript first received: March 19, 1992

Revised version accepted: August 13, 1992 